\title{
The effect of perceived security on consumer purchase intensions in electronic commerce
}

\author{
Aanchal Aggarwal* and Manmohan Rahul \\ Ansal University, \\ Golf Course Road, Sector 55, Gurugram, \\ Haryana 122003, India \\ Email: aanchalaggarwal10@gmail.com \\ Email: manmohanrahul@gmail.com \\ *Corresponding author
}

\begin{abstract}
The purpose of this paper is to explicate a comprehensive model explaining the impact of perceived security on consumer purchase intentions and how it contributes to trust and satisfaction towards an e-retailer in an online shopping context. Through an extensive literate review, it was found that two attributes of website personality, i.e., transaction security and payment system are constituents of perceived security. Thus, the study attempted to explore the relationships between transaction security, payment system and perceived security, trust, satisfaction and purchase intentions. The paper additionally provides valuable information to online retailers so as to maximise customer satisfaction and trust and generate positive intentions to buy online with perceived security attributes. In all, 500 Indian consumers' online shoppers were surveyed to conduct the above research agenda by structural equation modelling. A structural equation modelling approach was employed to explore the relationships between exogenous variables (transaction security, payment system and perceived security) and mediating variables (trust and satisfaction), with purchase intensions as a dependent variable. The finding of the study indicated that perceived security had positive effect on satisfaction. Perceived security has a positive impact on trust. Both trust and satisfaction had a positive mediating effect on consumer purchase intentions.
\end{abstract}

Keywords: website quality; perceived security; trust; satisfaction; purchase Intentions; B2C marketplace.

Reference to this paper should be made as follows: Aggarwal, A. and Rahul, M. (2018) 'The effect of perceived security on consumer purchase intensions in electronic commerce', Int. J. Public Sector Performance Management, Vol. 4, No. 1, pp.1-20.

Biographical notes: Aanchal Aggarwal is currently working as an Assistant Professor at the Vivekananda Institute of Professional Studies affiliated to Guru Gobind Singh Indraprastha University. She is a gold medalist in MBA (Insurance) from the Amity University. She is currently pursuing her $\mathrm{PhD}$ from the Ansal University, Gurgaon in the area of marketing and consumer behaviour. She holds a Fellowship Diploma from the Insurance Institute of India.

Manmohan Rahul is a postgraduate in Statistics, MBA from the FMS Udaipur and FDP in Management from the IIM Ahmedabad. He has done his Doctorate in International Business (Applied Economics Area) from the Agra University. He started his career with Telco in the year 1996, and thereafter sought career in academics. He has worked with Sharda Group, Amity Business School, 
Noida, and Institute of Management Studies, Dehradun, attended many national and international conferences and written books as core course material (for internal circulation). He started a newsletter as an editor and has ten publications in his credit. His area of interest is general management, international business, production and operation management and quantitative techniques for management. His interest also lies in writing cases and case analysis.

\section{Introduction}

Information communication technology (ICT) and online shopping are two of the most dynamic instigators of the emerging global economy. E-shopping and ICT gradually provide strategic possibilities and effective tools for monetary increase, the redeployment of wealth, and the expansion of equity around the arena (Buhalis, 2003). Also, the fast growth of the internet has strengthened way to the facts market, e-trade, and online markets - the internet is turning into greater state-of-the-art across all of these areas. Online transactions are leading in a new era for the net shopping enterprise, which is working to put into effect better business practices as referred by Buhalis (2003).

Banerjee (2017) stated that "demonetisation and a reduction in cash transaction, along with improvement of net banking facilities, can be opportunities for the Indian ecommerce sector The study suggested that in 2016, about 69 million consumers purchased online which is expected to cross 100 million by 2017 with the rise of digital natives, better infrastructure in terms of logistics, broadband and internet-ready devices to fuel the demand".

In the current scenario, there are "1.64 billion internet users in the international, up $305.5 \%$ from the year 2000" (Internet World Stats, 2009). The range of claimed net users has witnessed a compounded annual growth rate (CAGR) of $73 \%$ because December 2013. As of June 2016 there are 3.6 million mobile net users in rural India. This has grown 7.2 times in the recent years. The penetration of the computer literates some of the rural populace is $8.4 \%$ whilst the penetration of claimed net customers has grown from $2.68 \%$ in 2014 to $4.6 \%$ in 2016 . E-commerce which includes industrial transaction between seller and buyer over the net, enables a brand new financial surroundings and new commercial enterprise practices.

It is exciting to observe that "transactions of online shopping malls constitute $66.5 \%$ of total B2C marketplace transactions and on/offline mall transactions account for 33.5\% of the whole". Buhalis and Law (2008) cautioned that achieving a brand new records threshold of widespread, ubiquitous conversation has brought the whole e-commerce industry into a new level of interactivity, accelerating both wired and Wi-Fi management and advertising. "The number of consumers who purchase online is expected to cross 100 million by 2017 end with e-retail market likely jumping $65 \%$ on year in 2018 " (Banerjee, 2017). The online approach is ideal for the shopping enterprises in terms of allowing data retrieval and electronic transactions. In current years, increasingly more customers have taken advantage of the various benefits supplied by means of digital trade (Yoon, 2002). Yoon (2002) offered convenience, financial price, and product range as only a few of the attributes associated with the e-commerce uprising that has introduced approximately a fundamental trade in the dramatisation of commercial transactions. The 
range of internet customers has extended dramatically, but many users are unwilling to provide delicate personal data online because they do no longer agree with e-commerce security (Suh and Han, 2003; Yoon, 2002). Suh and Han (2003) "contend that online customers are able to get admission to vital files on computer systems all over the world due to the fact the internet become originally designed for research, now not for commerce. Adding to the uncertainty of e-commerce is the fact that the events to a transaction are not co-positioned and for this reason can't depend upon factors including physical proximity, hand-shakes, and body language".

The personality of the online shopping industry is perfectly suitable to the internet:

1 the product presented by the e-commerce industry is insubstantial

2 manufacturing and intake are not separable

3 demand seems perishable and varies appreciably (McCole, 2002).

As cautioned by Jin et al. (2007), trust is indispensable to all business transactions and that the part of trust measured in monetary transactions online may be a vital tool for marketing. However, there may be a scarcity of research concerning perceived trust with in online searching for online services and products. Trust performs a key role in transactions, and a lack of trust within online corporations is a number one cause why many purchasers pick not to shop digitally (Wu and Chang, 2006). Many preceding researches (Cyr, 2008) have examined trust in electronic commerce contexts collectively with other elements (Harris and Goode, 2004).

A few studies have been carried out on trust in the shopping e-commerce industry context in regards to different principles that are important to customer satisfaction (Wu and Chang, 2006). Furthermore, research has been very constrained regarding the perceived trust which encountered with the aid of skilled online consumers for online shopping. In this respect, this study take a look at which elements have an effect on purchase intensions. A structural equation modelling method was employed to inspect the associations among exogenous variables (transaction security, payment system), perceived security, trust, satisfaction and purchase intensions.

In this paper, we incorporated past studies to obtain two attributes of perceived security; transaction security, payment system in website personality that has a significant impact on the consumer purchase intentions. In order to explicate the impact of these attributes on the purchase intentions of the consumers we conducted a survey with the help of a questionnaire which was filled by 500 respondents who had prior online shopping experience. This survey will allow this study to effectively analyse the attributes of perceived security and their significant impact on consumer purchase intentions. The findings of this research have inferences for both researchers and practice.

\section{Theoretical background and research hypotheses}

\subsection{Perceived security}

This concept is one of the maximum tough issues confronted by consumers who need to buy services or products online and the issue comes from the susceptibilities of the internet site from which the product is bought (Suh and Han, 2003). It has also been cautioned that variables such as encryption, guard, confirmation, and authentication have 
to be the antecedents of perceived security, which affect the perceived security of clients (Chellappa and Pavlou, 2002). Because most of the people do not recognise if their information is being recorded, collected, and probably used later for illegal purposes, they may be turning into increasingly more aware of the way their records are being used. Moreover, clients are increasingly becoming cautious about giving out sensitive or delicate information at the internet (Yenisey et al., 2005). Thus, perceived security may be defined as "the subjective probability in the customer's eyes that his or her personal or financial information will not be shown, saved, and/or stolen during e-commerce and storage by outside parties" (Flavian et al., 2006). Researchers have regarded privacy as "the ability of an individual to control, manage, and selectively reveal personal information" (Eastlick et al., 2006). The safety of privateness is vital for online transactions. Liu et al. (2008) argued that the safety of privacy signifies transaction integrity and accordingly affects transaction choices. Belanger et al. (2002) in addition cautioned that a privacy announcement can enhance the perceived trustworthiness of e-carriers. To get rid of purchaser security issues, many online buying websites have evolved privacy regulations. This research evaluates two constituents of perceived security: transaction security and payment system. Many online customers hesitate on the ultimate moment to click the very last order button for a purchase after they affirm the transaction price. In fashionable, e-commerce reduces transaction prices which are defined as the prices of replacing statistics and incorporating selection procedures (Bunduchi, 2005). "Transaction risks, which can be defined as operation risks associated with the alternative parties in the transaction wilfully mishandling the transaction, and opportunism dangers associated with a lack of bargaining strength" (Bunduchi, 2005). However, online retailers achieving a higher level of online trust and a higher assessment of website features (Li et al., 2017).

\subsubsection{Transaction security}

At the purchase degree, privacy/security, price mechanisms, transaction abilities and speed of operation may have an effect on satisfaction. Compared with the traditional financial system, online purchasers are more keenly aware about the need for privacy/security (Culnan, 1999; Yianakos, 2002; Grewal et al., 2004; Park and Kim, 2003). Inadequate infrastructure, loss of trust with, and privacy and protection concerns regularly result in loss of income (Yianakos, 2002; Friedman et al., 2000; Grabner-Kraeuter, 2002; Liu et al., 2008). Moreover, online customers are recognised for low tolerance (Chen and Chang, 2003), it is far anticipated that, on common, online shoppers only look ahead to eight seconds for system feedback before bailing out (Dellaert and Kahn, 1999; Park and Kim, 2003). Besides affecting consumers' assessment of ordinary facts service, as mentioned earlier, warranty of protection also performs an essential position in consider forming via reducing the consumers' concerns about private data abuse and vulnerability of transaction records (Jarvenpaa and Todd, 1997; Ratnasingham, 1998). Consumers need distinct facts on how their private and transaction records are secured (Elliot and Fowell, 2000; Liu et al., 2008). So, if the perceived level of protection guarantee meets consumer's expectations, a consumer can 
be willing to reveal his/her personal information and try and buy with consolation. Therefore the following variables have been explored and developed under the construct of transaction security which is as follows:

1 "this website protects credit card information of customer

2 this site protects personal buying information

3 this site protects customer's e-mail address

4 this site does not illegally use customer information

5 overall the retailer's website is trustworthy

6 I feel safe in my transactions with the retailer's website" as given by Liu et al. (2008), Park and Kim (2003) and Shin et al. (2013).

\subsubsection{Payment system}

Security may be defined as defensive the information of transactions and clients from internal and external fraud/crook utilisation. People may also worry to transact and pay online, fearing that their personnel information is probably stolen. Security stays one of the most vital and properly researched areas of examine in payment systems (Abrazhevich, 2004). Concerns about security within the network location display that there want to be in addition improvements inside the electronic charge protocol to beautify trust in online charge structures. Due to the growth in financial institution mergers and acquisitions, customers are sceptical approximately the security of online bills (Abrazhevich, 2004). It is agreed that online sales are not as safe as traditional income; people are suspicious since there is no human factor involved within the sale and it is far performed in a digital setting (Whiteley, 2000). Online retailers achieves a higher level of online trust and a higher assessment of website features including payment procedure, privacy concerns, quality information (Li et al., 2017). The current literature recognises the safety concerns of customers and the impact they have at the adoption of payment systems (Lim et al., 2007). Customers often look forward to easy and convenient procedures of payment provided by an online shopping website which also created trust in the e-retailer. Therefore, (Özkan et al., 2010; Shin et al., 2013) developed the following variables for payment system in context to online shopping which are as follows:

1 "order procedure of this site is simple

2 order identification and payment are convenient

3 I trust the payment system of this site

4 this site often claims over payment

5 the instructions during payment procedure are clear".

Therefore with the help of the above review of literature the following hypothesis have been developed: 
H1 Perceived security is a second-order multidimensional construct comprising two dimensions: transaction security and payment system.

H2 Perceived security will have a significant positive effect on customer satisfaction.

H3 Perceived security will have a significant positive effect on customer trust.

H4 Perceived security will have a significant positive effect on customer purchase intensions.

\subsection{Trust}

Trust is a very significant factor in constructing long-term online relationships (Eastlick et al., 2006). Trust affects online purchase intentions. Yoon (2002) trust is regularly seen as a critical element in building B2C relationships with clients (Morgan and Hunt, 1994). Trust is dependent on the understanding of the sales clerk (Anderson and Narus, 1990). Therefore, electronic exchanges are believed to have higher dangers for clients because of absent of direct contact with the carrier personnel unlike physical stores (Pavlou et al., 2003). In the context of e-retail purchasers trust the e-carriers to offer correct records, truthful pricing regulations, privacy concerns, and accredited use of credit card and buy facts (Gefen et al., 2003). Consumers increase trust with the internet site store base on their experiences along with smooth functioning of website and clean fee approaches (Bart et al., 2005; Chen and Dibbs, 2010). While doing online shopping patron trust turns into a great factor to expand intentions to buy (Bart et al., 2005; Winch and Joyce, 2006). It is not always clean to imagine that customers will transact on e-retailing websites without improvement of agree with in that specific e-seller (Pang et al., 2007). Hwang and Kim (2007) argued that perceived security have a considerable impact on digital trust with online retailer. The relationship between trust and satisfaction is found to be significant as well (Kim et al., 2009b). Website personality is an important factor for customer satisfaction, customer trust that can positively affect purchase intention (Connolly and Bannister, 2008). Trust is a vital factor in facilitating consumer purchase intensions to shop online resulting in increase in final sales of the e-retailer (Huang and Chang, 2017):

H5 Customer trust will have a significant positive effect on purchase intention.

\subsection{Satisfaction}

The driver of website satisfaction includes security, privacy and so on (Bansal et al., 2004). There are many attributes associated with an internet site that presume the intentions to shop online with the aid of satisfaction being the mediating variable (Taylor and Strutton, 2009). Loiacono et al. (2002) said that satisfaction with website is a significant factor in facilitating purchase intentions. Srinivasan et al. (2002) have identified many attributes which can be important for pride from an internet site out of which transaction security and payment system are vital. Security, privacy and payment systems are the elements which have direct big effect on e-satisfaction (Kim et al., 2009b). Website character is a crucial component for customer satisfaction, customer trust which can definitely have an effect on purchase intensions. Purchase intentions are the important effect of satisfaction inside the context of e-trade (Bai et al., 2008). According to Ranganathan and Ganapathy (2002), Schaupp and Belanger (2005), Taylor 
and Strutton (2009) and Hausman and Siekpe (2009) perceived security consists of transaction security and payment system that increases the client satisfaction. Al-dweeri et al. (2017) stated that satisfaction plays a moderating effect in increasing purchase intensions and also plays a vital role in e-loyalty of the consumer:

H6 Customer satisfaction will have a positive significant effect on purchase intention.

\subsection{Purchase intentions}

Intentions to buy online could be an important issue to predict the shopping behaviour of customers in context of website quality, info search and merchandise analysis (Poddar et al., 2009; Hausman and Siekpe, 2009). There are several previous researches that have explored numerous factors of website temperament that drive client to buy online. For instance, conjointly transaction security and payment system affects online purchase intentions (Vijayasarathy, 2004; Richard, 2005). Jarvenpaa and Staples (2000) differentiated between ancient sort of looking and e-commerce and supported that trust could be a crucial issue for any online purchase intensions. Ranganathan and Ganapathy (2002) ended that security, privacy, site design, and information content are important for B2C platforms. Ha and Stoel (2009) expressed that technology options, looking conditions and merchandise worth plays an important role in customers intentions to get online. Understanding the relative importance of every of those factors is very important for e-vendors so as to draw in and retain customers. The drivers of website satisfaction includes security, privacy and so on (Bansal et al., 2004). There are many attributes associated with an internet site that presume the intentions to shop online with the aid of satisfaction being the mediating variable (Taylor and Strutton, 2009). Loiacono et al. (2002) said that satisfaction with website is a significant factor in facilitating purchase intentions. Trust is a very significant factor in constructing long-term online relationships (Eastlick et al., 2006). Trust affects online purchase intentions (Yoon, 2002). Trust is regularly seen as a critical element in building B2C relationships with clients (Morgan and Hunt, 1994). Website personality is an important factor for customer satisfaction, customer trust that can positively affect purchase intention (Connolly and Bannister, 2008). Teo and $\mathrm{Yu}$ (2005) explored that purchase intensions are being influenced by perceived security, trust and satisfaction. Website features including, privacy, security, designing increases the consumers purchase intensions ( $\mathrm{Li}$ et al., 2017). Al-dweeri et al. (2017) stated that satisfaction plays a moderating effect in increasing purchase intensions and also plays a vital role in e-loyalty of the consumer.

\section{Research method}

An extensive review of literature suggests that survey method has highly been accepted in conduct of prior studies. The quantitative results in conduct of any research study are highly dependent upon the knowledge of the respondents and their experiences in online shopping. The empirical data for the current study has been collected using the same method, i.e., the survey method. Online shoppers from four major metropolitan cities of India have participated in the survey. Respondents are from Hyderabad, Delhi, Mumbai and Bangalore. The selection of these cities was done to reduce bias and include opinions of people from distinct parts of the country. The survey message explaining the aim of 
the research study was circulated with the help of hyperlink among the online shoppers through social media platforms and mobile applications including e-mails, Facebook, LinkedIn, WhatsApp. The reason for selecting the above sources was their divergent and extensive reach and their popularity in India. The validity of the link was opened for one month for the respondents. The participants willingly responded to online questionnaire. After one month to get an effective response data the anomalies in the data were removed that included incomplete responses, duplicate IP addresses and e-mail accounts. The effective data was obtained after eliminating 72 responses from 572 responses resulting in sample size of 500 respondents.

\subsection{Measurement development}

The tool for the survey was designed for the respondents in a simplified manner which was easy to understand and respond. The questionnaire was divided into two parts: demographic profile and construct items. The demographic profile constituted details like age, income and gender of the respondent along with their experience in online shopping in the context if they have purchase via online shopping website or not. The research consists of six constructs, each having multiple statements or items that are measured using a nine-point Likert-type scale $(1=$ strongly disagree and $9=$ strongly agree $)$. The survey instrument was developed with the help of ten in-depth interviews done on qualitative basis. An extensive pilot test $(\mathrm{n}=113$, containing 113 online shoppers), which leads to the adoption of prevailing measurement scales wherever found appropriate. Then, purposive non-probability sampling was adopted which illustrated a sample of 500 online respondents who have previous experiences of online retailing and have used net banking in their transactions while purchasing online. In purposive sampling "The researcher chooses the sample based on who they think would be appropriate for the study. This is used primarily when there is a limited number of people that have expertise in the area being researched, or when the interest of the research is on a specific field or a small group". Additionally, in order to develop scales for measurement of all the constructs identified for the study such as site design, shopping convenience, trust, satisfaction and purchase intentions measures were adopted derived and modified from past studies. In order to test the projected interrelationships amid site design, shopping convenience, perceived usability, customer satisfaction, customer trust, purchase intention we performed structural equation modelling with the help of analysis of moment structure (AMOS). SEM permitted us to analyse the causative associations among ideas within the model to check if the model against the obtained information (Hair et al., 1998).

All the constructs adopted from the past studies are presented in Appendix A along with their measures and sources. Normal procedures for measuring were smeared that concerned the employment of multi-variable indicators for reliableness and unidimensionality. Shopping convenience was measured with four variables or things developed by Szymanski and Hise (2000) and Srinivasan et al. (2002). Website design was measured with four variables or things developed by Cristobal et al. (2007) and Kim et al. (2009b). Customer satisfaction was measured using three items established by Fan et al. (2013) and Kim et al. (2011). Customer trust was measured using four items developed by Kim et al. (2011) and Ngo and O'Cass (2012). Purchase intention was 
measured using three items developed by Hausman and Siekpe (2011), (see scale items in Appendix A).

\section{Results}

\subsection{Descriptive statistics}

Table 1 records the values of the means as well as the standard deviations of the constructs. The averages being $>3$ it was observed that the participants responded positively to the constructs of the study. Also, the coefficient values of the constructs are exceeding the conventional value of 0.7 the measurement scales for these constructs demonstrated a satisfactory level of reliability.

Table 1 Descriptive statistics (means and SD)

\begin{tabular}{lccc}
\hline Constructs & Mean & SD & Cronbach's $\alpha$ \\
\hline Transaction security & 7.0439 & 0.91599 & 0.85 \\
Payment system & 7.4099 & 1.10246 & 0.84 \\
Trust & 7.0439 & 0.86668 & 0.78 \\
Satisfaction & 7.3600 & 1.01811 & 0.76 \\
Purchase intentions & 6.5530 & .74705 & 0.86 \\
\hline
\end{tabular}

\subsection{Research sample demographic profile}

Table 2 illustrates the complete research sample profile. It demonstrates that $55.8 \%$ of the sample are males and remaining females has a purchase experience through online shopping websites. Also, Table 2 shows that $30.80 \%$ of the samples are aged between 25 and 35 which illustrated that majority of online shoppers are younger and more technology savvy which makes them more comfortable with the online purchase process. Also, respondents with an annual income of 2.5 lac to 10 lac are more comfortable with online shopping process.

Table 2 Research sample demographic profile

\begin{tabular}{lccc}
\hline Measure & Items & Frequency & Percentage \\
\hline Gender & Male & 279 & 55.8 \\
& Female & 221 & 44.2 \\
Age & Less than 25 & 87 & 17.4 \\
& $25-35$ & 154 & 30.8 \\
& $36-45$ & 136 & 27.2 \\
\multirow{4}{*}{ Annual income } & 45 and above & 123 & 24.6 \\
& $0-2.5$ lac & 101 & 20.2 \\
& Above 2.5-5 lac & 169 & 33.8 \\
& Above 5-10 lac & 154 & 30.8 \\
& Above 10 lac & 76 & 15.2 \\
\hline
\end{tabular}


Table 3 Dimensionality, reliability and convergent validity statistics

\begin{tabular}{|c|c|c|c|c|c|c|c|c|}
\hline Statements & & Constructs & $\begin{array}{c}\text { Standardised } \\
B\end{array}$ & S.E. & C.R. & $P$ & $\begin{array}{l}\text { Composite } \\
\text { reliability }\end{array}$ & $A V E$ \\
\hline TS6 & $<---$ & \multirow{6}{*}{$\begin{array}{l}\text { Transaction } \\
\text { security }\end{array}$} & 0.74 & 0.058 & 17.008 & & 0.885 & 0.561 \\
\hline TS5 & $<---$ & & 0.778 & & & $* * *$ & & \\
\hline TS4 & $<---$ & & 0.753 & 0.058 & 17.379 & & & \\
\hline TS3 & $<---$ & & 0.701 & 0.059 & 15.984 & $* * *$ & & \\
\hline TS2 & $<---$ & & 0.751 & 0.057 & 17.303 & $* * *$ & & \\
\hline TS1 & $<---$ & & 0.77 & 0.059 & 17.814 & $* * *$ & & \\
\hline PS5 & $<---$ & \multirow{5}{*}{$\begin{array}{l}\text { Payment } \\
\text { system }\end{array}$} & 0.882 & & & & 0.913 & 0.678 \\
\hline PS4 & $<---$ & & 0.84 & 0.039 & 24.596 & $* * *$ & & \\
\hline PS3 & $<---$ & & 0.802 & 0.039 & 22.681 & $* * *$ & & \\
\hline PS2 & $<---$ & & 0.766 & 0.039 & 21.024 & $* * *$ & & \\
\hline PS1 & $<---$ & & 0.824 & 0.039 & 23.773 & $* * *$ & & \\
\hline PI6 & $<---$ & \multirow{8}{*}{$\begin{array}{l}\text { Purchase } \\
\text { intentions }\end{array}$} & 0.755 & 0.074 & 16.264 & $* * *$ & 0.899 & 0.525 \\
\hline PI7 & $<---$ & & 0.725 & 0.067 & 15.616 & $* * *$ & & \\
\hline PI8 & $<---$ & & 0.735 & 0.069 & 15.82 & $* * *$ & & \\
\hline PI5 & $<---$ & & 0.723 & & & & & \\
\hline PI4 & $<---$ & & 0.716 & 0.068 & 15.422 & $* * *$ & & \\
\hline PI3 & $<---$ & & 0.71 & 0.063 & 15.273 & $* * *$ & & \\
\hline PI2 & $<---$ & & 0.72 & 0.066 & 15.507 & $* * *$ & & \\
\hline PI1 & $<---$ & & 0.714 & 0.067 & 15.361 & $* * *$ & & \\
\hline S6 & $<---$ & \multirow[t]{6}{*}{ Satisfaction } & 0.791 & 0.048 & 20.238 & $* * *$ & 0.915 & 0.642 \\
\hline S5 & $<---$ & & 0.82 & & & & & \\
\hline S4 & $<---$ & & 0.806 & 0.048 & 20.763 & $* * *$ & & \\
\hline S3 & $<---$ & & 0.819 & 0.046 & 21.243 & $* * *$ & & \\
\hline S2 & $<---$ & & 0.802 & 0.047 & 20.612 & $* * *$ & & \\
\hline S1 & $<---$ & & 0.767 & 0.048 & 19.364 & $* * *$ & & \\
\hline $\mathrm{T} 7$ & $<---$ & \multirow[t]{7}{*}{ Trust } & 0.751 & 0.06 & 16.673 & $* * *$ & 0.896 & 0.551 \\
\hline T6 & $<---$ & & 0.807 & 0.06 & 18.009 & $* * *$ & & \\
\hline T5 & $<---$ & & 0.748 & & & & & \\
\hline $\mathrm{T} 4$ & $<---$ & & 0.702 & 0.058 & 15.505 & $* * *$ & & \\
\hline $\mathrm{T} 3$ & $<---$ & & 0.714 & 0.059 & 15.8 & $* * *$ & & \\
\hline $\mathrm{T} 2$ & $<---$ & & 0.729 & 0.058 & 16.143 & $* * *$ & & \\
\hline $\mathrm{T} 1$ & $<---$ & & 0.741 & 0.057 & 16.428 & $* * *$ & & \\
\hline
\end{tabular}

Note: $* * * p<0.01$ 
We used confirmatory factor analysis (CFA) to evaluate the psychometric properties of the constructs. AMOS 18 was also used with maximum likelihood estimation (MLE) to evaluate the measurement model as shown in Table 4. Further during scale purification, standardised loadings from CFA were estimated (Hausman and Siekpe, 2009). As a whole fit indices confirmed a good fit with the data as shown in Table 4 (Chi-square: 623.612; CMIN/DF 1.248; GFI: 0.875; CFI: 0.977; RMR: 0.057; RMSEA: 0.022). The results established the spatial property of the results with discriminant validity. We also considered the validity and measured the dependability of the measures by calculation of composite reliabilities and average variance extracted (AVE) scores.

Table 4 Model fit

\begin{tabular}{lcccc}
\hline$C M I N / D F$ & $G F I$ & $R M R$ & $C F I$ & $R M S E A$ \\
\hline 1.248 & 0.875 & .057 & 0.977 & .022 \\
\hline
\end{tabular}

Table 5 Second-order factor of perceived usability

\begin{tabular}{lccccc}
\hline First order & Path & Second order & Estimate & S.E. & C.R. \\
\hline Transaction security & $<---$ & Perceived_Security & .757 & ------- & ------ \\
Payment system & $<---$ & Perceived_Security & .468 & .103 & 7.148 \\
\hline
\end{tabular}

Figure 2 AMOS results of SEM (see online version for colours)

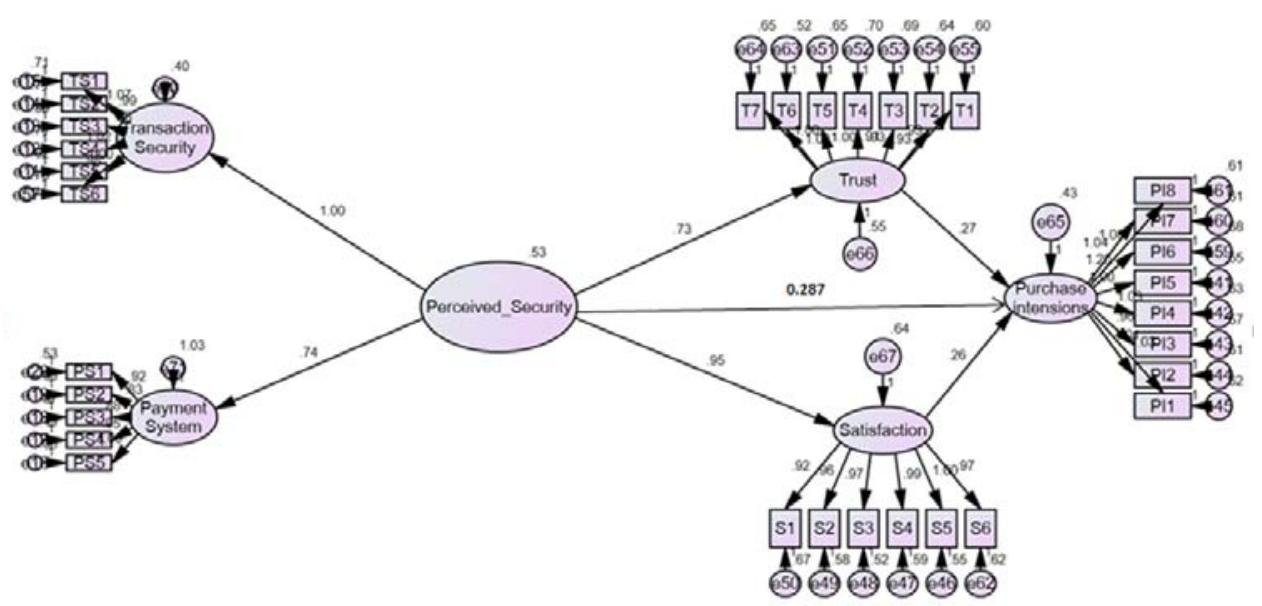

Using structural equation modelling, we tested the hypotheses in AMOS 18. Five indices are used to determine the model fit as shown in Table 7 were higher than the recommended standard by the literature $(\mathrm{DF}=1.254$, GFI $=0.935, \mathrm{RMR}=.121$, $\mathrm{CFI}=0.987$, RMSEA $=0.023$ ). Considering the sample size, our model is reasonably acceptable to assess the results.

Using structural equation modelling, we tested the hypotheses in AMOS 18. Five indices are used to determine the model fit as shown in Table 7 were higher than the recommended standard by the literature $(\mathrm{DF}=1.254$, GFI $=0.935, \mathrm{RMR}=.121$, $\mathrm{CFI}=0.987$, RMSEA $=0.023)$. Considering the sample size, our model is reasonably acceptable to assess the results. 
Table 6 Hypotheses testing results

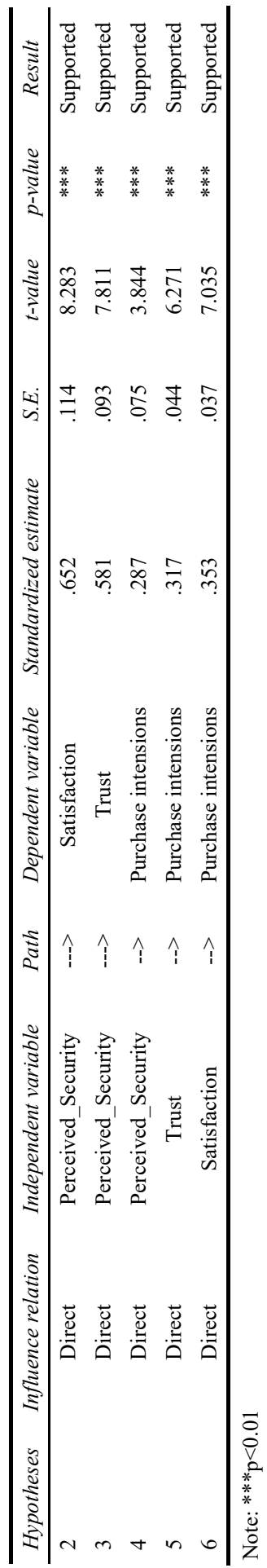


Table $7 \quad$ Model fit

\begin{tabular}{lcccc}
\hline$C M I N / D F$ & $G F I$ & $R M R$ & $C F I$ & $R M S E A$ \\
\hline 1.254 & 0.935 & .121 & 0.987 & .023 \\
\hline
\end{tabular}

\section{Discussion and conclusion}

In contemporary society, most of the people are coming across online buying, and a few are making superb use of digital trade (Tatnall and Lepa, 2001). E-retailers have willingly used the internet as a major marketing device for its services and products (Smith, 2008). Even although the wide variety of online users has swiftly accelerated, many people are reluctant to launch their private records to a website as they do now not consider e-commerce safety. A few researches on e-commerce have treated trust and satisfaction within the online purchasing environment for widespread online shopping products and services. Thus, the study aimed to develop a theoretical version of e-commerce in context to online shopping that consists of trust and satisfaction and to empirically take a look for the constructs which might be possibly to affect perceived security which in flip impacts purchase intention. The outcomes of this study suggest that six of six posited constructs of the constructs of the built standards exhibited extensively high quality coefficients and that the research model turned into therefore commonly possible. Our model shows that customers will buy products online if the e-trade internet site is perceived as secured.

The perception of safety as caused by using definite online privacy, protection of personal statistics, and risk free expenditures had a noticeably large effective impact on trust. Perceived security additionally had a drastically superb affect on satisfaction. These and different relationships were tested in preceding research and our findings are constant with different reviews (Fam et al., 2004; McCole, 2002). Although perceived security had a notably wonderful courting with trust and satisfaction. Possibly perceived security as related to privacy, bills, and private facts has a larger effect on trust with whilst clients are buying products and services online. With regard to satisfaction, the effects of our study are consistent with the ones of others (Suh and Han, 2003; Li et al., 2008; McKnight et al., 2002).

We found that satisfaction had a substantially wonderful impact on purchase intensions. Our findings are regular with the ones of previous studies (Kim et al., 2006; Bai et al., 2008; Teo and Liu, 2007). Our findings suggest that after consumers recall an internet purchase, satisfaction is in all likelihood to affect their level of purchase intensions, that's important for online purchasing (Corbitt et al., 2003). Satisfaction and Trust have substantially effective effects on purchase intensions (Lee et al., 2006; Jones and Leonard, 2008; McKnight and Chervany, 2001).

Furthermore, this study aims to observe which elements comprise of perceived security and whether it has an impact on purchase intensions. As this observe sheds light on figuring out the antecedents of trust and perceived security which also affects purchase intensions, our study might also make contributions to the theoretical framework for customer in the context of online shopping products. The findings of this study offer applied implications for advertising and marketers and practitioners who fabricate strategic plans and put into effect tools to improve the productivity or overall performance of online buying through $\mathrm{B} 2 \mathrm{C}$ e-commerce. For instance, our findings 
specify that trust is a predictor of purchase intensions. Thus, retailers who run e-commerce websites need to pay attention to improve clients' stage of trust and vendors of such sites should take note of customer satisfaction. We additionally notice that satisfaction is associated with purchase intensions because of perceived security, and transaction system. To improve the level of customers' trust with online shopping retailers may additionally need to provide customers' network website online so that clients could change their studies and get beneficial records on products earlier than they make definite purchases. Another crucial implication for e-retailers is associated with the function of perceived security. From our findings, protection for payments, privacy, and private records look like the maximum essential determinant of trust. Therefore, retailers need to pay careful attention to creating safe surroundings to shield their customers in phrases of perceived safety.

The final essential implication for e-store is associated with the function of transaction security and payment system. We located an especially considerable and effective relation with trust and satisfaction. Therefore, in order to enhance customers' trust online, the e-vendor ought to enhance the customer's satisfaction through high transaction security and payment mechanism. This study has one difficulty that's related to the dimension of perceived security. Analysing handiest two items of perceived security may be insufficient to build a sturdy version for the position of perceived security in online shopping. Future researchers may also want to conduct the same study with the inclusion of extra security-relevant items that allows you to enhance the statistical power and to reduce the possible for errors in this sort of studies. Thus, in future studies, offering a selected service or product may offer extra insightful course for instructional and managerial fields. Also, future researchers may additionally want to apply multi-group factor analysis in order to explore both low-and high-involvement products. These will vary in terms of online expenses products and services. E-retailers can be interested by identifying what these variations are considering this could help section online markets in phrases of client involvement.

\section{Limitations of the study}

The findings of this study ought to be understood with monition as a result of some limitations. First, this study is cross-sectional in nature attributable to that the implications of shopper's perspective modification would not be identified. Theoretical implications can be offered with a longitudinal study and qualitative in nature. Secondly, the study was conducted with a restricted sample of web shoppers employed from four major metropolitan cities of Republic of India. Additional studies will be necessary in alternative demographics so as to form the results in generalised form. Finally, this study examines the relationship between the constructs in a general way and no particular website has been involved. Thus the results may deviate in case of specific online retailers prominent in India.

\section{References}

Abrazhevich, D. (2004) Electronic Payment Systems: A User-Centered Perspective and Interaction Design, Dennis Abrazhevich. 
Al-dweeri, R.M., Obeidat, Z.M., Al-dwiry, M.A., Alshurideh, M.T. and Alhorani, A.M. (2017) 'The impact of e-service quality and e-loyalty on online shopping: moderating effect of e-satisfaction and e-trust', International Journal of Marketing Studies, Vol. 9, No. 2, p.92.

Anderson, J.C. and Narus, J.A. (1990) 'A model of distributor firm and manufacturer firm working partnerships', The Journal of Marketing, January, pp.42-58.

Bai, B., Law, R. and Wen, I. (2008) 'The impact of website quality on customer satisfaction and purchase intentions: evidence from Chinese online visitors', International Journal of Hospitality Management, Vol. 27, No. 3, pp.391-402.

Banerjee, N. (2017) Online Retail Consumers to Cross 100 Million by 2017: ASSOCHAMResurgent India, January [online] http://www.google.co.in/search?q=apa+citation+website\& ie $=$ utf-8\&oe=utf-8\&client $=$ firefox-b\&gfe_rd=cr\&ei=J9VCWby9GI3y8AeW4JaQDw (accessed 28 April 2017).

Bansal, H.S., McDougall, G.H., Dikolli, S.S. and Sedatole, K.L. (2004) 'Relating e-satisfaction to behavioral outcomes: an empirical study', Journal of Services Marketing, Vol. 18, No. 4, pp.290-302.

Bart, Y., Shankar, V., Sultan, F. and Urban, G.L. (2005) 'Are the drivers and role of online trust the same for all web sites and consumers? A large-scale exploratory empirical study', Journal of Marketing, Vol. 69, No. 4, pp.133-152.

Belanger, F., Hiller, J.S. and Smith, W.J. (2002) 'Trustworthiness in electronic commerce: the role of privacy, security, and site attributes', The Journal of Strategic Information Systems, Vol. 11, No. 3, pp.245-270.

Buhalis, D. (2003) 'Etourism: information technology for strategic tourism management', Annals of Tourism Research, Vol. 31, No. 3, pp. 740-741, Pearson Education, Great Britain.

Buhalis, D. and Law, R. (2008) 'Progress in information technology and tourism management: 20 years on and 10 years after the internet-the state of etourism research', Tourism Management, Vol. 29, No. 4, pp.609-623.

Bunduchi, R. (2005) 'Business relationships in internet - based electronic markets: the role of goodwill trust and transaction costs', Information Systems Journal, Vol. 15, No. 4, pp.321-341.

Chellappa, R.K. and Pavlou, P.A. (2002) 'Perceived information security, financial liability and consumer trust in electronic commerce transactions', Logistics Information Management, Vol. 15, Nos. 5/6, pp.358-368.

Chen, J. and Dibb, S. (2010) 'Consumer trust in the online retail context: exploring the antecedents and consequences', Psychology \& Marketing, Vol. 27, No. 4, pp.323-346.

Chen, S.J. and Chang, T.Z. (2003) 'A descriptive model of online shopping process: some empirical results', International Journal of Service Industry Management, Vol. 14, No. 5, pp.556-569.

Connolly, R. and Bannister, F. (2008) 'Factors influencing Irish consumers' trust in internet shopping', Management Research News, Vol. 31, No. 5, pp.339-358.

Corbitt, B.J., Thanasankit, T. and Yi, H. (2003) 'Trust and e-commerce: a study of consumer perceptions', Electronic Commerce Research and Applications, Autumn, Vol. 2, No. 3, pp.203-215.

Cristobal, E., Flavián, C. and Guinaliu, M. (2007) 'Perceived e-service quality (PeSQ) Measurement validation and effects on consumer satisfaction and web site loyalty', Managing Service Quality: An International Journal, Vol. 17, No. 3, pp.317-340.

Culnan, M.J. (1999) Georgetown Internet Privacy Policy Survey: Report to the Federal Trade Commission, Georgetown University, McDonough School of Business, Washington, DC.

Cyr, D. (2008) 'Modeling web site design across cultures: relationships to trust, satisfaction, and e-loyalty', Journal of Management Information Systems, Vol. 24, No. 4, pp.47-72.

Dellaert, B.G. and Kahn, B.E. (1999) 'How tolerable is delay?: Consumers' evaluations of internet web sites after waiting', Journal of Interactive Marketing, Vol. 13, No. 1, pp.41-54. 
Eastlick, M.A., Lotz, S.L. and Warrington, P. (2006) 'Understanding online B-to-C relationships: an integrated model of privacy concerns, trust, and commitment', Journal of Business Research, Vol. 59, No. 8, pp.877-886.

Elliot, S. and Fowell, S. (2000) 'Expectations versus reality: a snapshot of consumer experiences with internet retailing', International Journal of Information Management, Vol. 20, No. 5, pp.323-336.

Fam, K.S., Foscht, T. and Collins, R.D. (2004) 'Trust and the online relationship-an exploratory study from New Zealand', Tourism Management, Vol. 25, No. 2, pp.195-207.

Fan, Q., Yul Lee, J. and In Kim, J. (2013) 'The impact of web site quality on flow-related online shopping behaviors in C2C e-marketplaces: a cross-national study', Managing Service Quality: An International Journal, Vol. 23, No. 5, pp.364-387.

Flavián, C., Guinalíu, M. and Gurrea, R. (2006) 'The role played by perceived usability, satisfaction and consumer trust on website loyalty', Information \& Management, Vol. 43, No. 1, pp.1-14.

Friedman, B., Peter, H.K. Jr. and Howe, D.C. (2000) 'Trust online', Communications of the ACM, Vol. 43, No. 12, pp.34-40.

Gefen, D., Karahanna, E. and Straub, D.W. (2003) 'Trust and TAM in online shopping: an integrated model', MIS Quarterly, Vol. 27, No. 1, pp.51-90.

Grabner-Kraeuter, S. (2002) 'The role of consumers' trust in online-shopping', Journal of Business Ethics, Vol. 39, Nos. 1/2, pp.43-50.

Grewal, D., Iyer, G.R. and Levy, M. (2004) 'Internet retailing: enablers, limiters and market consequences', Journal of Business Research, Vol. 57, No. 7, pp.703-713.

Ha, S. and Stoel, L. (2009) 'Consumer e-shopping acceptance: antecedents in a technology acceptance model', J. Bus. Res., Vol. 62, No. 5, pp.565-71.

Hair Jr., J.F., Anderson, R.E., Tatham, R.L. and Black, W.C. (1998) Multivariate Data Analysis, Prentice-Hall, New Jersey.

Harris, L.C. and Goode, M.H. (2004) 'The four levels of loyalty and the pivotal role of trust: a study of online service dynamics', Journal of Retailing, Vol. 80, No. 2, pp.139-158.

Hausman, A.V. and Siekpe, J.S. (2009) 'The effect of web interface features on consumer online purchase intentions', Journal of Business Research, Vol. 62, No. 1, pp.5-13.

Huang, S.L. and Chang, Y. C. (2017) 'Factors that impact consumers' intention to shop on foreign online stores', in Proceedings of the 50th Hawaii International Conference on System Sciences, January.

Hwang, Y. and Kim, D.J. (2007) 'Customer self-service systems: the effects of perceived web quality with service contents on enjoyment, anxiety, and e-trust', Decision Support Systems, Vol. 43, No. 3, pp.746-760.

Internet World Stats (2009) Internet Usage Statistics: World Internet Users and Population.

Jarvenpaa, S.L. and Staples, D.S. (2000) 'The use of collaborative electronic media for information sharing: an exploratory study of determinants', The Journal of Strategic Information Systems, Vol. 9, No. 2, pp.129-154.

Jarvenpaa, S.L. and Todd, P.A. (1997) 'Is there a future for retailing on the internet', Electronic Marketing and the Consumer, Vol. 1, No. 12, pp.139-154.

Jin, B., Park, J.Y. and Kim, J. (2007) 'Cross-cultural examination of the relationships among firm reputation, e-satisfaction, e-trust, and e-loyalty', International Marketing Review, Vol. 25, No. 3, pp.324-337.

Jones, K. and Leonard, L.N.K. (2008) 'Trust in consumer-to-consumer electronic commerce', Information \& Management, Vol. 45, No. 2, pp.88-95.

Kim, H., Kim, T. and Shin, S.W. (2009a) 'Modeling roles of subjective norms and eTrust in customers' acceptance of airline B2C eCommerce websites', Tourism Management, Vol. 30, No. 2, pp.266-277. 
Kim, J.H., Kim, M. and Kandampully, J. (2009b) 'Buying environment characteristics in the context of e-service', European Journal of Marketing, Vol. 43, Nos. 9/10, pp.1188-1204.

Kim, M.J., Chung, N. and Lee, C.K. (2011) 'The effect of perceived trust on electronic commerce: shopping online for tourism products and services in South Korea', Tourism Management, Vol. 32, No. 2, pp.256-265.

Kim, S.H. and Park, H.J. (2011) 'Effects of social influence on consumers' voluntary adoption of innovations prompted by others', Journal of Business Research, Vol. 64, No. 11, pp.1190-1194.

Kim, W.G., Ma, X. and Kim, D.J. (2006) 'Determinants of Chinese hotel customers' e-satisfaction and purchase intentions', Tourism Management, Vol. 27, No. 5, pp.890-900.

Lanford, P. (2006) 'E-commerce: a trust perspective', International Conference on Internet Computing, pp.64-70.

Lee, H.Y., Ahn, H. and Han, I. (2006) Analysis of trust in the e-commerce adoption', in Proceedings of the 39th Hawaii International Conference on System Sciences, IEEE.

Li, R., Chung, T.L.D. and Fiore, A.M. (2017) 'Factors affecting current users' attitude towards e-auctions in China: an extended TAM study', Journal of Retailing and Consumer Services, Vol. 34, pp.19-29.

Li, X., Hess, T.J. and Valacich, J.S. (2008) 'Why do we trust new technology? A study of initial trust formation with organizational information systems', Journal of Strategic Information Systems, Vol. 17, No. 1, pp.39-71.

Lim, B., Lee, H. and Kurnia, S. (2007) 'Exploring the reasons for a failure of electronic payment systems: a case study of an Australian company', Journal of Research and Practice in Information Technology, Vol. 39, No. 4, pp.231-244.

Liu, X., He, M., Gao, F. and Xie, P. (2008) 'An empirical study of online shopping customer satisfaction in China: a holistic perspective', International Journal of Retail \& Distribution Management, Vol. 36, No. 11, pp.919-940.

Loiacono, E.T., Watson, R.T. and Goodhue, D.L. (2002) 'WebQual: a measure of website quality', Marketing Theory and Applications, Vol. 13, No. 3, pp.432-438.

McCole, P. (2002) 'The role of trust for electronic commerce in services', International Journal of Contemporary Hospitality Management, Vol. 14, No. 2, pp.81-87.

McKnight, D.H. and Chervany, N.L. (2001) 'Conceptualizing trust: a typology and e-commerce customer relationships model', in Proceedings of the 34th Hawaii International Conference on System Sciences, IEEE.

McKnight, D.H., Choudhury, V. and Kacmar, C. (2002) 'The impact of initial consumer trust on intentions to transaction with a website: a trust building model', Journal of Strategic Information Systems, Vol. 11, Nos. 3/4, pp.297-323.

Morgan, R.M. and Hunt, S.D. (1994) 'The commitment-trust theory of relationship marketing', The Journal of Marketing, July, Vol. 58, No. 3, pp.20-38.

Ngo, L.V. and O'Cass, A. (2012) 'In search of innovation and customer-related performance superiority: the role of market orientation, marketing capability, and innovation capability interactions', Journal of Product Innovation Management, Vol. 29, No. 5, pp.861-877.

Özkan, S., Bindusara, G. and Hackney, R. (2010) 'Facilitating the adoption of e-payment systems: theoretical constructs and empirical analysis', Journal of Enterprise Information Management, Vol. 23, No. 3, pp.305-325.

Pang, C., Yen, D.C. and Tarn, J.M. (2007) 'Exploring online shoppers' e-trust in China', Human Systems Management, Vol. 26, No. 3, pp.193-198.

Park, C.H. and Kim, Y.G. (2003) 'Identifying key factors affecting consumer purchase behavior in an online shopping context', International Journal of Retail \& Distribution Management, Vol. 31, No. 1, pp.16-29. 
Park, C.H. and Kim, Y.G. (2003) 'Identifying key factors affecting consumer purchase behavior in an online shopping context', International Journal of Retail \& Distribution Management, Vol. 31, No. 1, pp.16-29.

Pavlou, P.A. (2003) 'Consumer acceptance of electronic commerce: integrating trust and risk with the technology acceptance model', International Journal of Electronic Commerce, Vol. 7, No. 3, pp.101-134.

Poddar, A., Donthu, N. and Wei, Y. (2009) 'Web site customer orientations, web site quality, and purchase intentions: the role of web site personality', Journal of Business Research, Vol. 62, No. 4, pp.441-450.

Ranganathan, C. and Ganapathy, S. (2002) 'Key dimensions of business to consumer web sites', Information \& Management, Vol. 39, No. 6, pp.457-465.

Ratnasingham, P. (1998) 'The importance of trust in electronic commerce', Internet Research, Vol. 8, No. 4, pp.313-321.

Richard, M.O. (2005) 'Modeling the impact of internet atmospherics on surfer behavior', Journal of Business Research, Vol. 58, No. 12, pp.1632-1642.

Schaupp, L.C. and Belanger, F. (2005) 'A conjoint analysis of online consumer satisfaction', $J$. Electron Commerce Res., Vol. 6, No. 2, pp.95-111.

Shin, J.I., Chung, K.H., Oh, J.S. and Lee, C.W. (2013) 'The effect of site quality on repurchase intention in internet shopping through mediating variables: the case of university students in South Korea', International Journal of Information Management, Vol. 33, No. 3, pp.453-463.

Shin, J.I., Chung, K.H., Oh, J.S. and Lee, C.W. (2013) 'The effect of site quality on repurchase intention in Internet shopping through mediating variables: the case of university students in South Korea', International Journal of Information Management, Vol. 33, No. 3, pp.453-463.

Smith, T.J. (2008) 'Senior citizens and e-commerce websites: the role of perceived usefulness, perceived ease of use, and web site usability', Informing Science: International Journal of an Emerging Trans discipline, Vol. 11, pp.59-83.

Srinivasan, S.S., Anderson, R. and Ponnavolu, K. (2002) 'Customer loyalty in e-commerce: an exploration of its antecedents and consequences', Journal of Retailing, Vol. 78, No. 1, pp.41-50.

Suh, B. and Han, I. (2003) 'The impact of trust and perception of security control on the acceptance of electronic commerce', International Journal of Electronic Commerce, Vol. 7, No. 3, pp.135-161.

Szymanski, D.M. and Hise, R.T. (2000) 'E-satisfaction: an initial examination', Journal of Retailing, Vol. 76, No. 3, pp.309-322.

Tatnall, A. and Lepa, J. (2001) 'Researching the adoption of e-commerce and the internet by older people', in The 2nd International We-B Conference, Perth, Australia.

Taylor, D.G. and Strutton, D. (2009) 'Has e-marketing come of age? Modeling historical influences on post-adoption era Internet consumer behaviors', Journal of Business Research [online] http://dx.doi.org/10.1016/j.jbusres.2009.01.018.

Taylor, S.A. and Baker, T.L. (1994) 'An assessment of the relationship between service quality and customer satisfaction in the formation of consumers' purchase intentions', Journal of Retailing, Vol. 70, No. 2, pp.163-178.

Teo, T.S. and Yu, Y. (2005) 'Online buying behavior: a transaction cost economics perspective', Omega, Vol. 33, No. 5, pp.451-465.

Teo, T.S.H. and Liu, J. (2007) 'Consumer trust in e-commerce in the United States, Singapore, and China', Omega: The International Journal of Management Science, Vol. 35, No. 1, pp.22-38.

Vijayasarathy, L.R. (2004) 'Predicting consumer intentions to use on-line shopping: the case for an augmented technology acceptance model', Information \& Management, Vol. 41, No. 6, pp.747-762.

Whiteley, D. (2000) E-Commerce: Strategy, Technologies and Applications, McGraw-Hill Publishing Company. 
Winch, G. and Joyce, P. (2006) 'Exploring the dynamics of building, and losing, consumer trust in B2C eBusiness', International Journal of Retail \& Distribution Management, Vol. 34, No. 7, pp.541-555.

Wu, J.J. and Chang, Y.S. (2006) 'Effect of transaction trust on e-commerce relationships between travel agencies', Tourism Management, Vol. 27, No. 6, pp.1253-1261.

Yenisey, M.M., Ozok, A.A. and Salvendy, G. (2005) 'Perceived security determinants in e-commerce among Turkish university students', Behaviour \& Information Technology, Vol. 24, No. 4, pp.259-274.

Yianakos, C. (2002) 'Nameless in cyberspace: protecting online privacy', $B+F S$, Vol. 116, No. 6, p.48.

Yoon, S.J. (2002) 'The antecedents and consequences of trust in online-purchase decisions', Journal of Interactive Marketing, Vol. 16, No. 2, pp.47-63. 


\section{Appendix A}

\begin{tabular}{|c|c|}
\hline Scale & Items \\
\hline \multirow{6}{*}{$\begin{array}{l}\text { Transaction security } \\
\text { (Liu et al., 2008; Park } \\
\text { and Kim, 2003) }\end{array}$} & This website protects credit card information of customer \\
\hline & This site protects personal buying information \\
\hline & This site protects customer's e-mail address \\
\hline & This site does not illegally use customer information \\
\hline & Overall the retailer's website is trustworthy \\
\hline & I feel safe in my transactions with the retailer's website \\
\hline \multirow{6}{*}{$\begin{array}{l}\text { Payment system (Özkan } \\
\text { et al., 2010) }\end{array}$} & Order procedure of this site is simple \\
\hline & Order identification and payment are convenient \\
\hline & I trust the payment system of this site \\
\hline & This site often claims over payment \\
\hline & The instructions during payment procedure are clear \\
\hline & Order procedure of this site is simple \\
\hline \multirow{7}{*}{$\begin{array}{l}\text { Trust (Kim and Park, } \\
\text { 2011; Ngo and O'Cass, } \\
\text { 2012) }\end{array}$} & Online shopping sites have integrity \\
\hline & Online shopping sites are reliable \\
\hline & Online shopping sites are trustworthy \\
\hline & I feel safe in my transactions with the retailer's website \\
\hline & I trust the retailer's website to keep my personal information safe \\
\hline & Overall the retailer's website is trustworthy \\
\hline & $\begin{array}{l}\text { I feel that any information communicated by the retailer's website is } \\
\text { secure }\end{array}$ \\
\hline \multirow{6}{*}{$\begin{array}{l}\text { Satisfaction (Kim and } \\
\text { Park, 2011; Fan et al., } \\
\text { 2013) }\end{array}$} & Overall I was satisfied with this online commerce \\
\hline & The online shopping site information content met my needs \\
\hline & It was easy to buy product I chose \\
\hline & I was satisfied with online buying when compared to offline buying \\
\hline & My choice to purchase from this site was wise one \\
\hline & I am satisfied with my decision to purchase from this website \\
\hline \multirow{8}{*}{$\begin{array}{l}\text { Purchase intentions } \\
\text { (Hausman and Siekpe, } \\
\text { 2011; Shin et al., 2013) }\end{array}$} & $\begin{array}{l}\text { I intend to continue to purchase from this shopping website in the } \\
\text { future }\end{array}$ \\
\hline & I will recommend this shopping website to my friends or relatives \\
\hline & I will continue using (internet provider) for my online services \\
\hline & $\begin{array}{l}\text { If there is a product that I want to purchase, I would like to use the } \\
\text { online store }\end{array}$ \\
\hline & I am encouraged to revisit this site in the near future \\
\hline & It is likely that I will purchase through this site in the near future \\
\hline & I expect to purchase through this site in the near future \\
\hline & I will definitely buy products from this site in the near future \\
\hline
\end{tabular}

